\title{
Dissecting the Left Heart Hypoplasia by Pluripotent Stem Cells
}

\author{
Junko Kobayashi, Shunji Sano, and Hidemasa Oh
}

\section{Keywords}

Hypoplastic left heart syndrome • Pluripotent stem cells • Disease modeling

The genetic background of hypoplastic left heart syndrome (HLHS) is still unknown. Cardiac differentiation from pluripotent stem cells (PSCs) can recapitulate the cardiogenesis in vitro, and PSC technology could be useful to dissect the diseases with the complex mechanisms. In the past few years, some researches were reported to seek the pathogenesis of HLHS by using PSCs. This paper reports the achievements.

1. Gaber $\mathrm{N}$ et al. showed that human embryonic stem cells (hESCs) during cardiovascular lineage with hypoxia recapitulated the phenotype of the HLHS heart, which was characterized by increased expression of the oncogenes and TGF- $\beta 1$, damaged DNA, and senescence with cell cycle arrest [1]. The phenotypes were rescued by TGF- 31 inhibition.

2. Jiang $\mathrm{Y}$ et al. generated disease-specific induced pluripotent stem cells (iPSCs) from a patient with HLHS [2]. HLHS-iPS-derived cardiomyocytes demonstrated repression of MESP1, TNNT2, and delayed expression of GATA4 compared with hESCs and control-iPSCs. HLHS-iPS-derived cardiomyocyte showed calcium oscillation under caffeine and inositol trisphosphate receptor upregulation, presumably as a result of ryanodine receptor dysfunction.

\footnotetext{
J. Kobayashi $(\bowtie) \cdot S$. Sano

Department of Cardiovascular Surgery, Okayama University Graduate School of Medicine,

Dentistry, and Pharmaceutical Sciences, Okayama, Japan

e-mail: junko-k@okayama-u.ac.jp

H. Oh

Department of Regenerative Medicine, Center for Innovative Clinical Medicine, Okayama

University Hospital, Okayama, Japan
}

T. Nakanishi et al. (eds.), Etiology and Morphogenesis of Congenital Heart Disease, DOI 10.1007/978-4-431-54628-3_47 


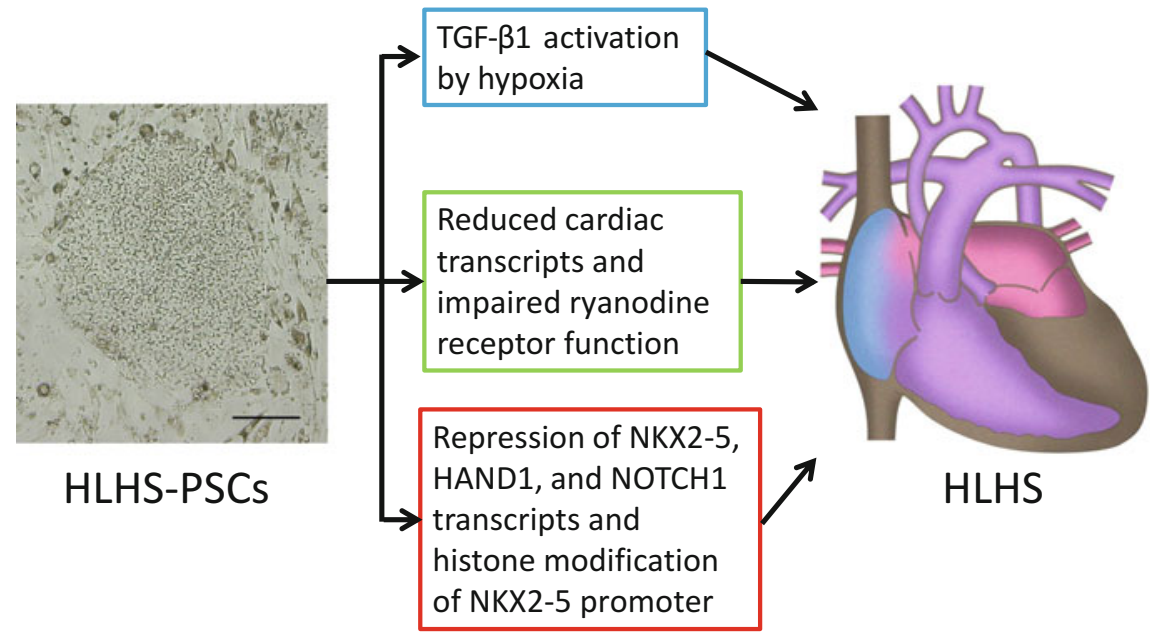

Fig. 47.1 PSC technology models HLHS. Three possible mechanisms of HLHS were unveiled by PSCs. Bar, $200 \mu \mathrm{m}$

3. Kobayashi $\mathbf{J}$ et al. generated five HLHS-iPSC lines and found repression of the transcripts such as NKX2-5, HAND1, HAND2, NOTCH1, HEY1, HEY2, and TBX2 in HLHS-iPS-derived cardiomyocytes [3]. The promoter activities of SRE, TNNT2, and NPPA were suppressed in HLHS-derived cardiac progenitor cells and iPSCs compared with those from bi-ventricle (BV). All promoter activities of both cell types could be fully restored by co-transfection of NKX2-5, HAND1, and NOTCH1, and co-transfection of the shRNAs into BV-derived cells reduced the promoter activation. HLHS-derived cardiomyocytes demonstrated repressed $\mathrm{H} 3 \mathrm{~K} 4 \mathrm{me} 2$ and acH3 and increased H3K27me3 in NKX2-5 promoter, implying suppressed NKX2-5 promoter activity.

Taken together, the PSC technology can be useful to dissect the complex heart diseases. Further investigation using this technique is necessary to determine the pathogenesis of HLHS (Fig. 47.1).

Open Access This chapter is distributed under the terms of the Creative Commons AttributionNoncommercial 2.5 License (http://creativecommons.org/licenses/by-nc/2.5/) which permits any noncommercial use, distribution, and reproduction in any medium, provided the original author(s) and source are credited.

The images or other third party material in this chapter are included in the work's Creative Commons license, unless indicated otherwise in the credit line; if such material is not included in the work's Creative Commons license and the respective action is not permitted by statutory regulation, users will need to obtain permission from the license holder to duplicate, adapt or reproduce the material. 


\section{References}

1. Gaber N, Gagliardi M, Patel P, et al. Fetal reprogramming and senescence in hypoplastic left heart syndrome and in human pluripotent stem cells during cardiac differentiation. Am J Pathol. 2013;183:720-34.

2. Jiang Y, Habibollah S, Tilgner K, et al. An induced pluripotent stem cell model of hypoplastic left heart syndrome (HLHS) reveals multiple expression and functional differences in HLHSderived cardiac myocytes. Stem Cells Trans Med. 2014;3:416-23.

3. Kobayashi J, Yoshida M, Tarui S, et al. Directed differentiation of patient-specific induced pluripotent stem cells identifies the transcriptional repression and epigenetic modification of NKX2-5, HAND1, and NOTCH1 in hypoplastic left heart syndrome. PLoS One. 2014;9(7): e102796. 